\title{
Effect of sowing time and density for vegetative and reproductive traits of genotypes of maize landrace in an agroecological system
}

\author{
Anderson Munarini ${ }^{1,2^{*}}$ (i) Rubens Onofre Nodari $^{1}{ }^{(0)}$ \\ ${ }^{1}$ Programa de Pós-graduação em Recursos Genéticos Vegetais, Universidade Federal de Santa Catarina (UFSC), Florianópolis, SC, Brasil. \\ ${ }^{2}$ Universidade Federal de Santa Catarina (UFSC), 88034-001, Florianopolis, SC, Brasil. E-mail: andermpa@gmail.com. *Corresponding author.
}

ABSTRACT: Family farmers preserve the tradition of cultivating maize landrace varieties because these plants have characteristics that hybrids lack. The greatest challenge in conserving in situ on-farm genetic diversity is avoiding gene flow and genetic introgression of transgenes to landrace varieties. Thus, farmers are obliged to change sowing times to guarantee temporal isolation since most farms are small, making spatial isolation impossible. The objective of the present work was to evaluate the behavior of maize landrace varieties submitted to different sowing times and densities in an agroecological system. The test was conducted in sub-sub-divided plots, where the main plot was represented by the sowing time, the sub-plot by the genotype, and the sub-sub-plot by the density, with three replications, for two consecutive years. The results demonstrate the effect of sowing time and density on the characteristics evaluated. In western Santa Catarina, the best time to sow seeds of maize landrace varieties in an agroecological system is in September, which is when the varieties expressed the greatest potential at densities from 45,000 to 50,000 pl.hat , but it will not avoid transgene contamination.

Key words: Zea mayz ssp. mays L., in situ on-farm conservation, genotype x environment interaction, grain productivity.

Efeito de época e densidade de semeadura nas características vegetativas e reprodutivas em genótipos de variedades crioulas de milho em sistema de base agroecológica

RESUMO: Famílias camponesas preservaram a tradição do cultivo das variedades crioulas de milho estimuladas por características que os híbridos não apresentam. Sendo, o maior desafio para a conservação da diversidade genética in situ on farm evitar o fluxo gênico e a introgressão genética de trangenes nas variedades crioulas. Nesse sentido, os agricultores são obrigados a alterar épocas de semeadura para garantir isolamento temporal uma vez que a maioria das áreas é pequena inviabilizando o isolamento no espaço. O objetivo do presente trabalho foi avaliar o comportamento de variedades crioulas de milho em sistema de base agroecológica submetidas às diferentes épocas e densidades de semeadura. No ensaio conduzido em parcelas sub-sub-divididas, a parcela principal foi representada pela época, a sub-parcela pelo genótipo e a sub-sub-parcela pela densidade, com três repetições, por dois anos consecutivos. Os resultados demostraram efeito de época e densidade de semeadura nas características avaliadas. É possível indicar que a época mais adequada para semeadura de variedades crioulas de milho em sistema de base agroecológica é em setembro para o oeste de Santa Catarina, sendo que para essa época as variedades expressaram maior potencial de produtividade de grãos na faixa de densidade de 45000 a 50000 pl.ha ${ }^{-1}$, mas não impedirá a contaminação por transgene.

Palavras chave: Zea mayz ssp mays L. Conservação in situ on farm, interação genótipo x ambiente, produtividade de grãos.

\section{INTRODUCTION}

Maize, an American cereal originally from Mexico, has been selected and dispersed by different people and today is cultivated in most countries. Since Europeans arrived in America, maize has been one of the most important cereals to humanity as a food for people and other animals. Today, it is one of the main sources of proteins and carbohydrates for humans in many Latin American and African countries (SHIFERAW et al., 2011).
A great diversity of maize has been created over time from variants that emerged and were recombined and selected in distinct environments. HERNANDEZ (2012) compiled data from studies in all American countries and listed approximately 300 maize races. According to GROBMAM (1961), this diversity is explained by the numerous environments that maize is cultivated in association with mutations, hybridizations and the strong intentional selection process made by indigenous and traditional peoples. 
Genetic improvement practices used by seed improvement and breeding companies have brought cultivars of maize hybrids to market that spread rapidly since the 1960 s due to incentives given to farmers (i.e., technical assistance and financing). Later, transgenic hybrid maize cultivars came to dominate the maize seed market and in 2019 comprised more than $88.9 \%$ of the area planted with maize in Brazil (CÉLERES, 2019).

However, many family farmers preserve the tradition of cultivating maize landrace varieties (NERLING et al., 2013). Recently, a diversity census was conducted in western Santa Catarina State that identified 1,513 maize landraces conserved by family famers, including 1,078 popcorn, 337 common maize, 61 sweet maize and 37 flour maize varieties, representing expressive phenotypic diversity and use, as well as the presence of wild relatives (COSTA, F. M. et al., 2017).

The existing genetic diversity in the landrace varieties allowed natural selection and selection practiced by farmers that promoted adaption to different environments, even far from domestication centers where characteristic properties were developed and fixed in different genotypes, many of which are not found in other regions or the region of origin (NODARI \& GUERRA, 2015).

Studies show the technical and economic feasibility of producing maize landrace varieties in agroecological systems. However, adjustments in crop management are still needed to improve the efficiency of the system (ALTIERI et al., 2012). For example, the arrangement of maize plants can be manipulated by changing the number of plants per area. The best arrangement of plants in the field is that which allows the best use of light, water and nutrients by the maize cultivar (ROMANO et al., 2007).

Sowing time of maize affects yield, although it does not affect production cost. The different responses of genotypes to environmental variability means that genotypic and environmental effects are not independent. Thus, to know the best sowing time, it is important to analyze the entire crop cycle so all the environmental conditions during the phenological phases can be predicted (FORSTHOFER et al., 2006).

In addition, there are not enough scientific data that farmers could use to manage landrace sowing time and density to preserve the landrace identity and to obtain high productivity. Therefore, the objective of the present work was to evaluate maize landrace varieties submitted to different sowing times and densities in an agroecological system.

\section{MATERIALS AND METHODS}

The tests were installed on a family farm in the municipality of Chapecó, SC $\left(27^{\circ} 03^{\prime} 21.26^{\prime \prime}\right.$ $\mathrm{S}, 52^{\circ} 40^{\prime} 07.13$ " W, average of $690 \mathrm{~m}$ elevation). A soil analysis showed $3.7 \%$ organic matter, $138 \mathrm{ppm}$ potassium, 4 ppm phosphorous and a $\mathrm{pH}$ of 5.7. The experiment was conducted in sub-sub-divided plots, with three replications, where the main plot represented the sowing time, the sub-plot represented the genotype and the sub-sub-plot represented the sowing density. The first sowing time was on 10 and 12 September, the second was on 11 and 14 November and the third was on 14 and 15 January, respectively, of the 2016/2017 and 2017/2018 growing seasons. All of the times were based on the climate risk zoning for the crop (MAPA, 2015). The densities were the following: 25,000; 40,000; 55,000 and 70,000 pl.ha-1.

Of the four maize varieties used, three were landraces called Branco Precoce, Taquara and Língua de Papagaio, which were cultivated by heritage seed farmers in western Santa Catarina. These landraces have characteristics that differentiate them from others, such as cycle, height and grain type (Figure 1). The fourth was an open pollinated commercial variety called SCS 155 Catarina that is commonly cultivated in Santa Catarina State.

The experimental unit comprised five rows, $5 \mathrm{~m}$ long and spaced $0.7 \mathrm{~m}$ apart, of which the area used was the central 3 rows, totaling 10.5 $\mathrm{m}^{2}$. At the time of sowing, the seeds were evenly distributed in the furrows with twice as many seeds as necessary to obtain the four desired plant densities. When the plants were in stage V2 of the RITCHIE et al. (1993) scale, thinning was conducted to get the desired plant populations, according to the treatments of each plot.

In the tests, it was used $1800 \mathrm{~kg} \mathrm{ha}^{-1}$ of organic compost fertilizer containing poultry litter (Ferticel). Manual weeding was used to control invasive plants. The control of lepidoptera was performed 30 days after emergence in all plots of the sowing times of November and January, when level of economic damage was reached (CRUZ \& TULPIN, 1982), with the spray of $500 \mathrm{~g} / \mathrm{ha}$ of Bac-Control Max WP, a product based on Bacillus thuringiensis that has bioinsecticidal activity.

The following was determined in the area used in the plots according to the minimum descriptors of the crop (IBPGRI, 1991): male flowering, female flowering, plant height and cob height. The percentage of lodged plants, broken plants and the stem diameter were determined according to SANGOI et al. (2000). 


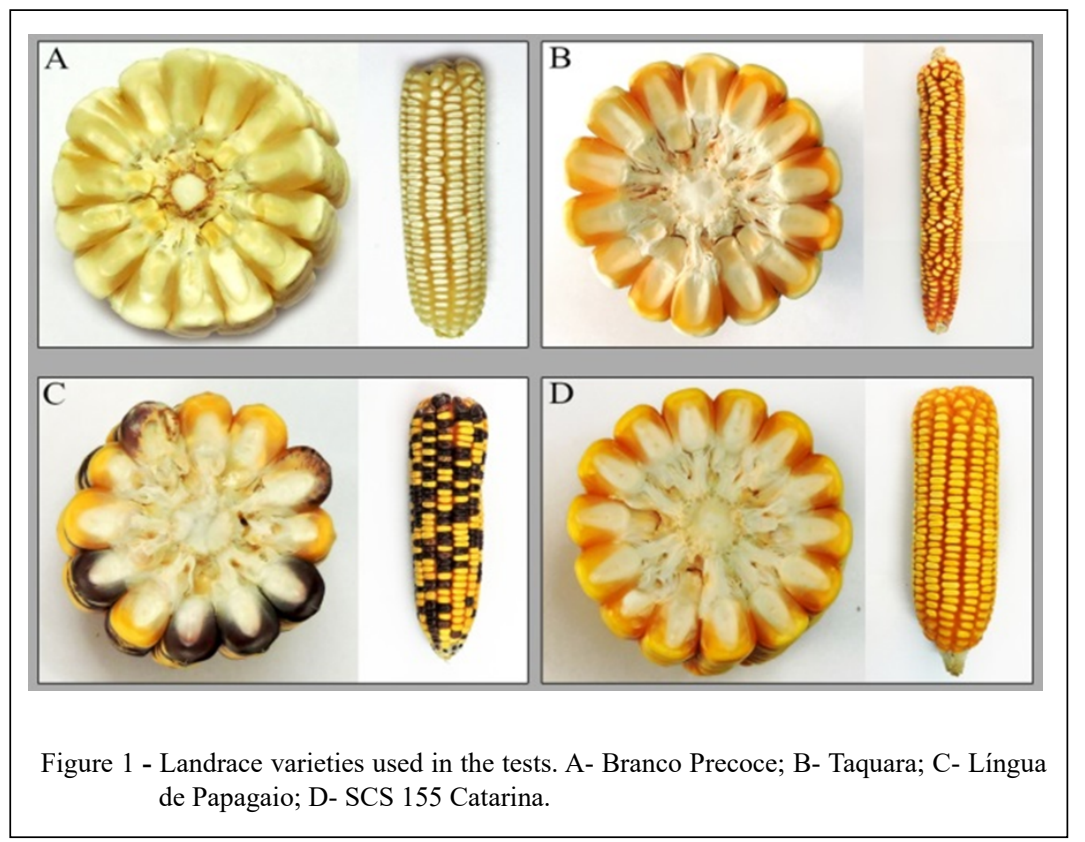

Grain productivity, adjusted to ton.ha ${ }^{-1}$, was determined according to UATE et al. (2015).

Analyses of variance were made individually per year and with the combined data of both years. The $\mathrm{F}$ values for the main effects and interactions were considered significant at the $5 \%$ $(\mathrm{P}>0.5)$ significance level. When significant, the mean plant densities were compared with a regression analysis, testing the linear and quadratic models. The means of the genotypes and sowing times were compared with the Tukey test. The two analyses of the means were made at the $5 \%$ significance level. The statistical analyses were made using the program $\mathrm{R}$.

\section{RESULTS AND DISCUSSION}

Differences were found for the evaluated characteristics between genotypes, sowing times and growing seasons and, for this reason, the averages are presented individually for each year. In addition, statistically simple interactions for all characteristics evaluated and the triple for grain productivity were observed.

There was no effect of the different crop densities for male and female flowering of the landrace genotypes evaluated. In all, the emission of male flowers occurred before the female flowers because maize plants are protandrous. Differences were also found in the cycles of the genotypes within and between sowing times (Figure 2). The Língua de Papagaio genotype was the latest and the Branco Precoce was the earliest, independent of the year and sowing time.

However, the sowing time affected the phenology of the genotypes tested. For example, for Língua de Papagaio, the later the sowing time, the fewer the number of days between sowing and male (Figure 2 A, B) and female (Figure 2 C, D) flowering. The other genotypes exhibit a similar behavior when sown in November and January. The results of the present work agree with those obtained by BERGAMASCHI (2006), since thermal availability directly influences phenological development of the plants and development is faster during warmer periods. Thus, in hotter regions or times there is more precocious development.

During the kernel dough stage, the Branco Precoce genotype had the lowest plant height values, while the Língua de Papagaio had the highest values (Figure $3 \mathrm{~A}, \mathrm{~B}$ ). These results indicate the existence of genetic variability in the varieties evaluated for this characteristic. High genetic variability in plant height was also found in another study of maize landrace and commercial varieties (FALCÃO et al., 2017).

Plant height is also affected by the interaction genotype $\mathrm{X}$ time in the present study. The Língua de Papagaio, Taquara and SCS 155 Catarina genotypes were taller when sown in January, differing from sowing in September (Figure 3 A, B). The Branco Precoce genotype exhibited a similar pattern, 


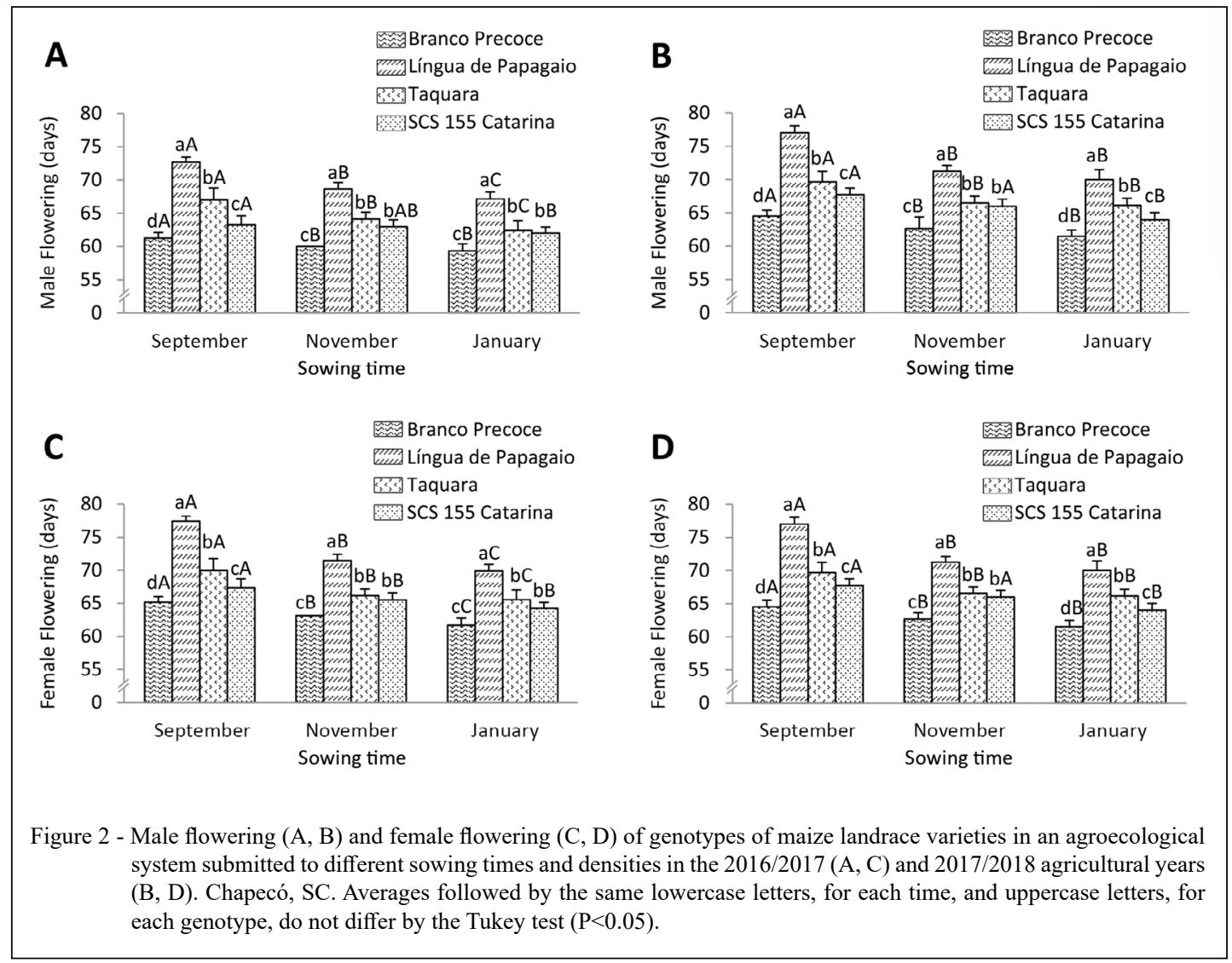

but only in the 2017/2018 agricultural year (Figure 3 B). For sowing before the middle of September, the air and soil temperatures and solar radiation are lower, which results in shorter plants with a smaller leaf area (PIANA et al., 2008). Effect for sowing time on plant height was also found by CARON et al. (2017), who attributed the decrease in height to the shorter genotype cycle at a certain sowing time.

In relation to density, only sowing in January of the 2016/2017 agricultural year had a linear increase in plant height as sowing density increased (Figure $3 \mathrm{C}$ ). At the other times and agricultural year there was no effect of the density on plant height (Figure $3 \mathrm{C}, \mathrm{D})$. This result corroborates that of BALBINOT JÚNIOR et al. (2007), who evaluated varieties of open pollinated maize at four sowing densities and did not observe an effect of density on plant height. Additionally, the results of the present work were similar to those of PAIVA et al. (2015), who evaluated the performance of maize landrace varieties under different sowing densities in the semi-arid region of Paraíba.

For cob height, there was a difference between the genotypes for all sowing times, and
Língua de Papagaio had the highest averages and Branco Precoce had the lowest averages for this characteristic (Figure 3 E, F). The genotypes exhibited different behaviors for cob height at different sowing times; in the 2016/2017 growing season, three genotypes exhibited a shorter cob height when sown in September compared to November and January (Figure $3 \mathrm{E}$ ). The time $\mathrm{X}$ genotype interaction was also found in studies by UATE et al. (2015).

In the 2017/2018 growing season, the Língua de Papagaio genotype exhibited a linear decrease in the average height of cobs as the sowing density increased (Figure $3 \mathrm{H}$ ). The remaining genotypes were not influenced by sowing density (Figure $3 \mathrm{G}, \mathrm{H}$ ), which agrees with the results of PAIVA et al. (2015), who did not verify an influence of density on the insertion height of cobs in varieties tested.

In the present study, an effect was detected for the time $\mathrm{x}$ density interaction and stem diameter in the 2016/2017 agricultural year (Figure 4 A). In the two agricultural years there was a linear effect in the decreasing stem diameter as plant density increased (Figure 4A, B). These results are similar to those obtained 


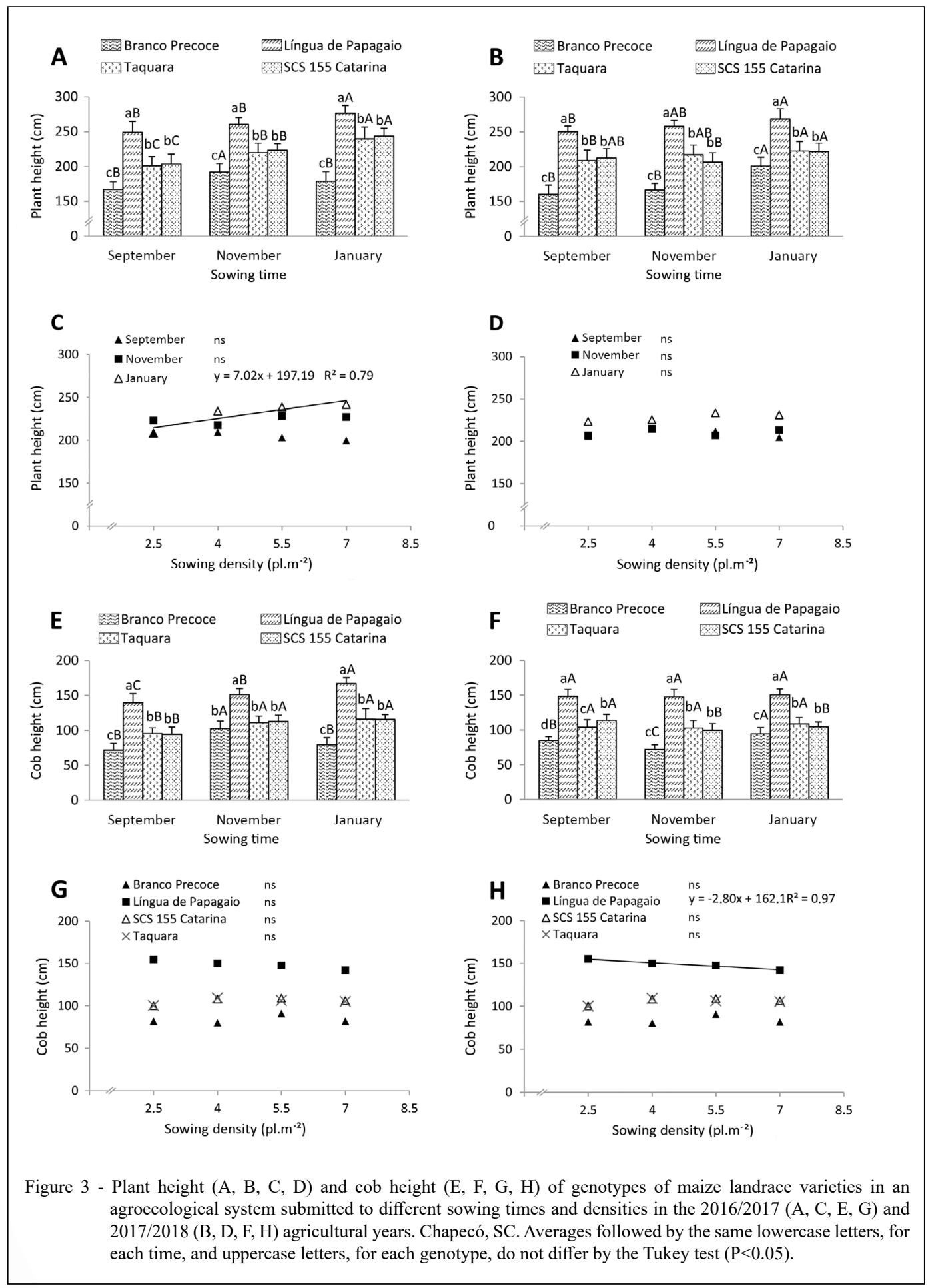

by BALBINOT JÚNIOR. et al. (2007) and PAIVA et al. (2015) when evaluating open pollinated maize varieties.

Regarding lodged plants, the four varieties used in the present study did not differ among themselves, since they exhibited satisfactory levels of lodged plants (below 3\%) for the September sowing. However, for the later sowings the behavior of the genotypes differed, from 

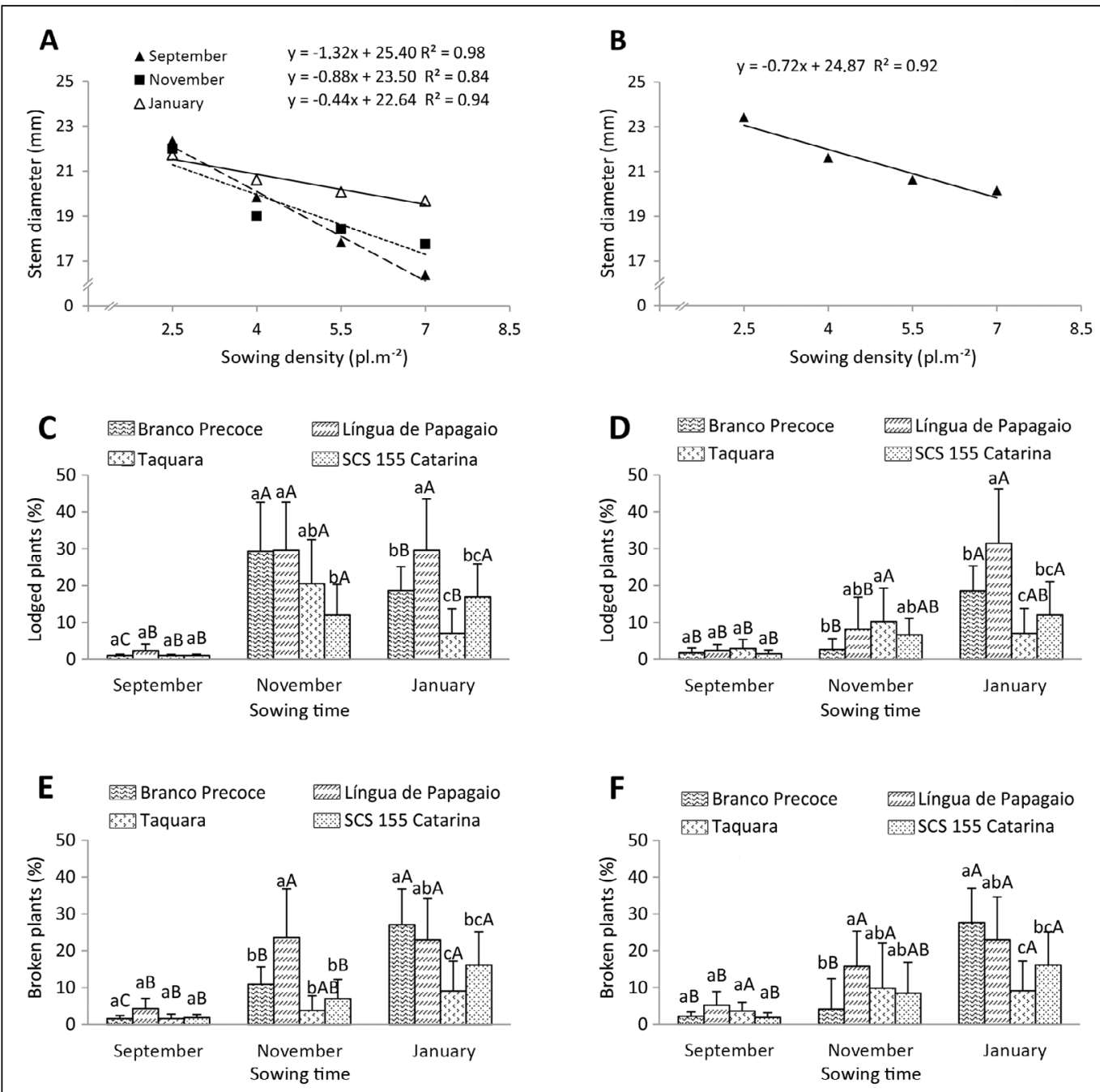

Figure 4 - Stem diameter (A, B), lodged plants (C, D) and broken plants (E, F) of genotypes of maize landrace varieties in an agroecological system submitted to different sowing times and densities in the 2016/2017 (A, C, E) and 2017/2018 (B, D, F) agricultural years. Chapecó, SC. Averages followed by the same lowercase letters, for each time, and uppercase letters, for each genotype, do not differ by the Tukey test $(\mathrm{P}<0.05)$.

the early sowing, since the percentage of lodged plants increased (Figure $4 \mathrm{C}, \mathrm{D}$ ).

The sowing time $\mathrm{x}$ genotype interaction was also observed for the percentage of broken plants, whose averages for the varieties tested also differed according to sowing time. The Língua de Papagaio and Branco Precoce varieties presented an increase in broken plants for the November and January sowings, while the SCS 155 Catarina genotype had a low percentage of broken plants for the September and November sowings, which increased for the January sowing. An increase in lodged and broken plants when sowing was late occurred due to the reduction in the emergence-tasseling subperiod, less accumulation of reserves in the stem, and precarious development of the radicular system (SERPA et al., 2012). Considering the absence of difference in the percentage of broken plants for the sowing times in the 2017/2018 agricultural year, the Taquara genotype might have a genetic base that contributes to stem resistance under late sowing conditions (Figure $4 \mathrm{E}, \mathrm{F}$ ).

Similarly, the sowing time $\mathrm{x}$ genotype $\mathrm{x}$ density interaction was found for the grain productivity characteristic. The present study indicates that sowing 
in September and November, when the genotypes presented a quadratic behavior for sowing density, results in the greatest grain productivity.

The effect of sowing time was also verified by COSTA, R.V. da et al. (2017), who observed a drastic decrease in productivity for late sowing. ALI et al. (2018) notes that the sowing date is one of the key-point in the management of maize to optimize productivity, since different dates result in different responses. In Ali et al. (2018) study, the results show that sowing maize really early or late has a negative effect on grain yield.
The quadradic behavior with an increase in the population of plants $\mathrm{ha}^{-1}$ is also exhibited by hybrids for plant densities between 25,000 and 125,000 pl.ha ${ }^{-1}$ (SANGOI et al., 2007 and PEREIRA et al., 2009). In September, a greater grain yield potential was expressed when sown at densities of 45,000 and 50,000 pl.ha ${ }^{-1}$ in the 2016/2017 and 2017/2018 agricultural years, respectively (Figure 5 A, B). In the first growing season, the Branco Precoce genotype exhibited similar values for the September and November sowing times (Figure $5 \mathrm{~A}, \mathrm{C}$ ); however, in the same growing season Taquara and SCS 155

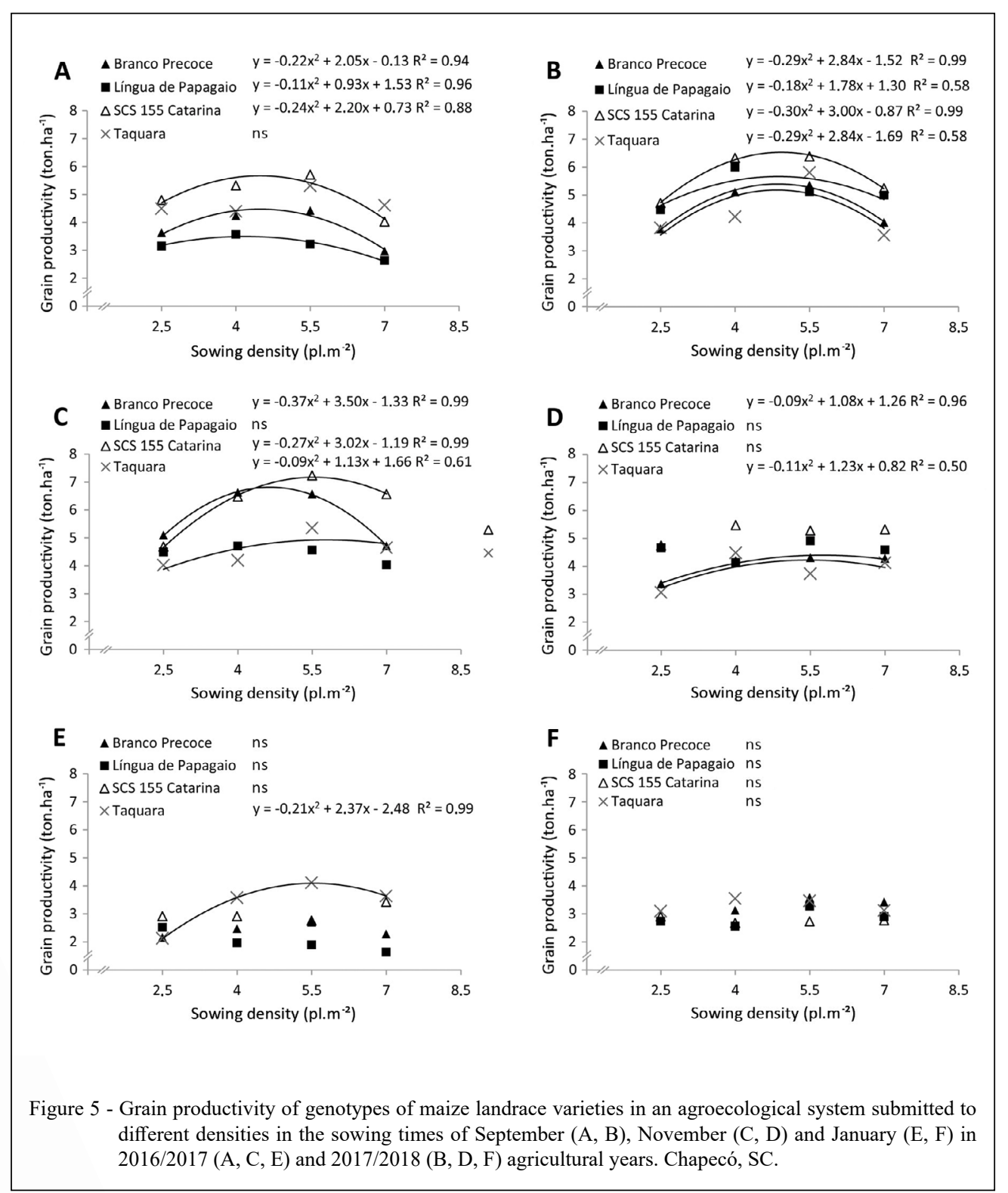

Ciência Rural, v.51, n.5, 2021. 
Catarina sown in November presented higher grain yield when sown at densities of 55,000 to 60,000 pl.ha ${ }^{-1}$, respectively, while grain yield of Língua de Papagaio was not affected by density (Figure $5 \mathrm{C}$ ). In November of the 2017/2018 agricultural year, only Branco Precoce and Taquara exhibited an effect from sowing density, with greater productive potential for the 55,000 to 60,000 pl.ha $^{-1}$ densities, respectively (Figure $5 \mathrm{D}$ ).

The results of the present study are similar to those of KANDIL (2014) that tested densities of $53,000,64,000$ and 80,000 pl.ha $^{-1}$ and verified better productivity averages for hybrids at the intermediate density. Additionally, BALBINOT JÚNIOR et al. (2007) concluded that a density of 45,000 to 55,000 plants ha-1 was the best to maximize productivity of open pollinated corn varieties in an agroecological production system.

However, SANGOI et al. (2019) and KANDIL et al. (2017) suggest that studies related to an increase in the density of maize plants should be conducted by observing different spacing between the rows because, for hybrids, an increase in density accompanied by a decrease in spacing between the rows results in better grain productivity due to the better distribution of plants that favors photosynthesis by increasing light penetration into the canopy.

For the January sowings, the low productivity did not allow to discriminate the density effects (Figure 5 E, F). The lack of difference in genotypes can also be explained by the increase in the percentages of lodged and broken plants in November and January (Figure 4 C, D, E, F).

Differently from September sowing, the leptidoptera were present in level of economic damage at November and January sowing times, which control was done with bioisenticide based on Bacillus thuringiensis. This fact also contributed to lower the grain productivity and increase production costs in the later sowing times.

Since the sowing time that provide the highest grain productivity for the landraces it is also the same time recommended to sow the conventional or transgenic hybrids. One way to avoid gene flow from other maize varieties (e.g. conventional and transgenic hybrids) is the flowering temporal isolation when spatial isolation is not possible. Under this condition, if farmers want to preserve de genetic background of the cultivated landraces, they need to postpone the sowing to later times, which is subject to penalties such as grain yield decrease and lodged and broken plants increase.

\section{CONCLUSION}

Our study demonstrated that sowing in September is adequate and at this time, the genotypes of the maize landraces evaluated in an agroecological system expressed greater potential at a density range of 45,000 to $50,000 \mathrm{pl}^{-h^{-1}}$. With penalties in grain productivity, tentatively farmers can increase the strength of flowering temporal isolation by using later sowing times in order to preserve the landrace genetic identity.

\section{ACKNOWLEDGEMENTS}

The authors would like to thank the Oestebio Cooperative and the Small Farmers Movement (MPA) for their partnership in the field experiments. We also thank the Coordenação de Aperfeiçoamento de Pessoal de Nível Superior (CAPES) (Finance code 001) for the scholarships awarded to AM, and the Conselho Nacional de Desenvolvimento Científico e Tecnológico (CNPq) for the fellowships awarded to AM and RON.

\section{DECLARATION OF CONFLICT OF INTERESTS}

The authors declare that there is no conflict of interest. The funding entities had no influence on the study design; nor in the collection, analysis or interpretation of the data; in the writing of the manuscript, nor in the decision to publish the results.

\section{AUTHOR CONTRIBUTIONS}

The authors equally contributed to the manuscript.

\section{REFERENCES}

ALI, W. et al. Influence of sowing dates on varying maize (Zea mays L.) varieties grown under agro-climatic condition of Peshawar, Pakistan. European Journal of Experimental Biology, v.8, n.6, p.36. 2018. Available from: <https:/www.imedpub.com/articles/influence-ofsowing-dates-on-varying-maize-zea-mays-i-varieties-grown-underagroclimatic-condition-of-peshawar-pakistan.php?aid=23804>. Accessed: Feb. 01, 2020. doi: 10.21767/2248-9215.100077.

ALTIERI, M. A. et al., Agroecologically efficient agricultural systems for smallholder farmers: contributions to food sovereignty. Agron. Sustain. Dev., v.32, n.1, p.1-13. 2012. Available from: $<$ https://link.springer.com/article/10.1007/s13593-011-0065-6>. Accessed: Jul. 15, 2015. doi: 10.1007/s13593-011-0065-6.

BALBINOT JÚNIOR., A. A., et al. Plant density in maize openpollinated varieties. Revista de Ciências Agroveterinárias, v.6, n.2, p.114-124. 2007. Available from: <http://www.revistas.udesc. br/index.php/agroveterinaria/article/view/5365/3570>. Accessed: Sep. 24, 2017.

BERGAMASCHI, $\mathrm{H}$. et al. Water deficit and yield in maize crop. Brasília, Pesquisa Agropecuária Brasileira, v.41, n.2, p.243-249. 2006. Available from: <https://seer.sct.embrapa.br/index.php/pab/ article/view/7130/4175>. Accessed: Feb. 12, 2016. 
CARON, B. O. et al. Weather elements on morphological and productive characteristics of corn in different sowing times. Científica. v.45, n.2, p.105-114, 2017. Available from: <http:// dx.doi.org/10.15361/1984-5529.2017v45n2p105-114>. Accessed: Mar. 22, 2019. doi: 10.15361/1984-5529.

CÉLERES. Informativo de Biotecnologia CÉLERES. Editor: Anderson Galvão. PDF. Empresa Céleres de Consultoria. Uberlândia - MG, nov. 2019. Available from: <https://www. celeres.com.br>. Accessed: May, 20, 2020.

COSTA, F. M. et al. Maize diversity in southern Brazil: indication of a microcenter of Zea mays L. Genet Resour Crop Evol. v.64, p.681700. 2017. Available from: <https://doi.org/10.1007/s10722-0160391-2>. Accessed: Jan. 18, 2020. doi: 10.1007/s10722-016-0391-2.

COSTA, R. V. da. et al. Corn cultivars affected by sowing time at off-season in Tocantins, Brazil. Revista Brasileira de Milho e Sorgo, v.16, n.3, p.469-480. 2017. Available from: <https://doi. org/10.18512/1980-6477/rbms.v16n3p469-480>. Accessed: Aug. 23, 2019. doi: 10.18512/1980-6477.

CRUZ, I.; TURPIN, F. T. Effect of Spodoptera frugiperda on different growth stages of corn. Pesquisa Agropecuária Brasileira. v.17, n.3, p.355-359. 1982. Available form: <https:// seer.sct.embrapa.br/index.php/pab/article/view/15641>. Accessed: Jul. 07, 2014.

FALCÃO, R. F. et al. Evaluation of free pollination populations, commercials and creole varieties corn in two municipalities of Alagoas. Cultura Agronômica, v.26, n.4, p.611-624. 2017. Available from: <https://doi.org/10.32929/24468355.2017v26n4p611-624>. Accessed: Jul. 06, 2018.

FORSTHOFER, E. L. et al. Agronomic yield and economic performance of maize in different management levels and sowing times. Pesquisa Agropecuária Brasileira, v.41, p.399407. 2006. Available from: <https://doi.org/10.1590/S0100204X2006000300005>. Accessed: Jul. 02, 2018.

GROBMAM, A. et al. Races of maize in Peru, their origins, evolution and classification. Washington. National Academy of Sciences/National Research Council. 1961. 374p. Available from: $<\mathrm{https}$ ://www.ars.usda.gov/ARSUserFiles/50301000/Races_of Maize/RoM_Peru_0_Book.pdf $>$. Accessed: Mar. 05, 2020.

HERNANDEZ, J. A. S. El origen y la diversidad del maíz em el continente amerirano. Universidad Autónoma de la Ciudad de México. Greenpeace. 2ed. Sep 2012. Available from: <https:// issuu.com/greenpeacemexico/docs/origen_del_maiz_/39>. Accessed: Aug. 02, 2017.

IBPGRI. Descriptors for maize. 1991. 86p. Rome: International Board for Plant Genetic Resources. Available from: $<\mathrm{https} / /$ www.bioversityinternational.org/e-library/publications/detail/ descriptors-for-maizedescriptores-para-maizdescripteurs-pour-lemais/>. Accessed: Jan. 12, 2019.

KANDIL, A. A. et al. Maize hybrids yield as affected by inter and intra row spacing. International Journal of Environment, Agriculture and Biotechnology, v.2, n.2. 2017. Available from: <http://dx.doi.org/10.22161/ijeab/2.2.11>. Accessed: Jan. 12, 2020. doi: $10.22161 /$ ijeab.

KANDIL, E. E. E. Determine independent population density for each maize hybrid (Zea mays L.). International Conference on
Agriculture and Biotechnologyb IPCBEE, v.79. 2014. Available from: <http://www.ipcbee.com/vol79/006-ICABT2014-L0017. pdf $>$. Accessed: Dec. 20, 2018. doi: 10.7763/IPCBEE.

MAPA. ZARC - Zoneamento Agrícola de Risco Climático. Brasília: Ministério da Agricultura, Pecuária e Abastecimento. 2015. Available from: <http://indicadores.agricultura.gov.br/zarc $>$. Accessed: May, 24, 2015.

NERLING, D. et al. Conservation and multiplication of landraces and varities seeds by farmers of the Movement of Small Farmers of Santa Catarina. Cadernos de Agroecologia, v.8, n.2. 2013. Available from: <http://revistas.aba-agroecologia.org.br/index. $\mathrm{php} / \mathrm{cad} /$ article/view/13655>. Accessed: Jan. 30, 2020.

NODARI, R. O.; GUERRA, M. P. A agroecologia: Estratégias de pesquisa e valores. Estudos Avançados, v.29, n.85. 2015. Available from: $\quad<$ https://doi.org/10.1590/S0103-40142015000100010>. Accessed: Jun. 20, 2018. doi: 10.1590/S0103-40142015000100010.

PAIVA, R. S. de A. et al. Answer the landrace maize to different population densities in the soil and climatic conditions of the backlands of Paraiba. ACSA, v.11, n.1, p.120-125. 2015. Available from: http://revistas.ufcg.edu.br/acsa/index.php/ACSA/article/ view/538 Accessed: Jun. 23. 2018. doi: 10.30969.

PEREIRA, J. L. A. R. et al. Corn responses to fertilizer rates and sowing densities. Ciência e Agrotecnologia, v.33, n.3, p.676683. 2009. Available from: <http://dx.doi.org/10.1590/S141370542009000300003>. Accessed: Sep. 25, 2019. doi: 10.1590/ S1413-70542009000300003.

PIANA, A. T. et al. Plant density of hybrid maize at early sowing date in Southern Brazil. Ciência Rural, v.38, p.26082612. 2008. Available from: <https://doi.org/10.1590/S0103$84782008005000023>$. Accessed: Nov. 13, 2019. doi: 10.1590 / S0103-84782008005000023.

RITCHIE, S. W. et al. How a corn plant develops. Ames: Iowa State University of Science and Technology. 1993. 26p. (Special Report, 48). Available from: $<$ https://lib.dr.iastate.edu/cgi/viewcontent.cgi ?article $=1045 \&$ context $=$ specialreports $>$. Accessed: Jan. 22, 2019.

ROMANO, M. R. et al. Performance of five landraces maize in different production systems. Resumos do V CB. Rev. Bras. de Agroecologia, v.2, n.2. 2007. Available from: $<$ http://revistas.abaagroecologia.org.br/index.php/rbagroecologia/article/view/7348>. Accessed: Sep. 23, 2016.

SANGOI, L. et al. Management of plant arrangement to optimize grain productivty in maize. Revista Brasileira de Milho e Sorgo, v.18, n.1, p.47-60. 2019. Available from: <https://doi. org/10.18512/1980-6477/rbms.v18n1p47-60>. Accessed: Feb. 02, 2019. doi: $10.18512 / 1980-6477$.

SANGOI, L. et al. Leaf area and grain yield of maize hybrids at different plant populations. Revista Brasileira de Milho e Sorgo, v.6, n.3, p.263-271. 2007. Available from: <http://rbms.cnpms. embrapa.br/index.php/ojs/article/view/231>. Accessed: Oct. 22, 2019. doi: $10.18512 / 1980-6477$.

SANGOI, L. et al. Disease incidence and severity of four maize hybrids grown at different plant densities. Ciência Rural, v.30, n.1, p.17-21. 2000. Available from: <https://doi.org/10.1590/ S0103-84782000000100003>. Accessed: Apr. 25, 2020. doi: 10.1590/S0103-84782000000100003. 
SHIFERAW, B. et al. Crops that feed the world 6. Past successes and future challenges to the role played by maize in global food security. Food Sec., v.3, p.307-327. 2011. Available from: $<$ https:// doi.org/10.1007/s12571-011-0140-5>. Accessed: May, 10, 2020. doi: 10.1007/s12571-011-0140-5.
UATE, J. V. et al. Sowing date and spatial distribution of plants in maize production. Revista Brasileira de Milho e Sorgo, v.4, n.3, p.346-357. 2015. Available from: <http://rbms.cnpms.embrapa. br/index.php/ojs/article/view/509>. Accessed: Sep. 25, 2019. doi: 10.18512/1980-6477.

Ciência Rural, v.51, n.5, 2021. 